\title{
Comparison of lipid character of sediments from the Great Lakes and the Northwestern Atlantic
}

\author{
MARY J. LeENHeER \\ Cities Service Oil and Gas Corp., Box 3908, Tulsa, OK 74102, U.S.A. \\ Kristine D. Flessland and Philip A. Meyers \\ Department of Atmospheric and Oceanic Science. The University of Michigan. Ann Arbor. MI 48109. \\ U.S.A \\ (Receited 13 September 1983; accepted 13 April 1984)

\begin{abstract}
Geolipid compositions of surficial sediments from Lake Michigan. Lake Huron, and from three locations in the Northwestern Atlantic were determined to compare source inputs and alteration processes in different sedimentary environments. Fatty acids, sterols, fatty alcohols, and alkanes were examined in both unbound and bound extracts of these samples. Significant amounts of long chain fatty acids. alcohols, and hydrocarbons are present in the deep ocean station, yet this location contains a proportionally larger amount of short chain geolipids than do marine stations closer to shore. Larger proportions of long chain lipids present in the Lake Michigan, Lake Huron, and Gulf of Maine samples relative to the open ocean samples reflect larger inputs of land-derived lipids to sediments closer to terrigenous sources. Marine samples contain a more complex mixture of sterols than is found in lake sediments, suggesting that sterol inputs and alteration processes in the marine environment are more complex than in lacustrine settings. Ratios of $16: 1 / 16: 0$ and $18: 1 / 18: 0$ fatty acids decrease with increasing distance from land, which suggests that fatty acid degradation before and during deposition becomes more extensive in the open deeper ocean stations.
\end{abstract}

Key words: hydrocarbons. alkanes, alcohols, fatty acids, lacustrine and marine sediments

\section{INTRODUCTION}

Organic matter present in surficial sediments is composed of the remains of plants and animals which have been degraded and weathered to varying degrees during transport to the sediment. The degree to which the sedimentary organic matter is altered before burial is dependent on a number of factors: the length of time before deposition, the resistance of the organic matter to alteration, and the extent of reworking after deposition (i.e. by bioturbation and aeration). The organic matter present in different depositional environments reflects the effects of the specific combination of these factors acting in each environment.

Lipid distributions present in young subaqueous sediments have been studied in different environments. Brooks et al. $(1976,1977)$ studied fatty acid and hydrocarbon distributions in modern sediments from three English lakes and from three coastal marine locations. Similarly, Meyers and Takeuchi (1979) compared the fatty acid and hydrocarbon distributions of various sedimentary environments in Lake Huron. Organic matter inputs over depositional history have been characterized by distributions of fatty acids, alkanes, and sterols in sediments of Mono Lake (Reed, 1977) and Cam Loch (Cranwell, 1977). Sterols appear to be particularly useful source indicators and have been studied in sediments from estuarine (Huang and Meinschein, 1976, 1978), marine (Lee et al., 1979. 1980; Gagosian et al., 1980; Wardroper et al., 1978) and lacustrine (Gaskell and Eglinton, 1976; Nishimura and Koyama, 1976, 1977) areas. These reports show that geolipid distributions in marine and lacustrine sediments differ with time and location and reflect changes in organic matter input, alteration, and preservation.

The studies mentioned above represent the beginnings of the effort to understand the processes which are responsible for the fate of lipids in sedimentary environments. Thus, lipid distributions in surficial sediments reflect the character of the lipids being deposited, the nature of the sedimentary environment, and the rate at which they are being buried. The oxicity of the sediment, the amount of bioturbation, and the deposition rate influence the degree of reworking which occurs before permanent burial. The extent of diagenesis is also dependent on the reactiveness of the various lipid classes. Further comparison of the lipid distributions present in the surficial sediments from different environments will allow a better understanding of these processes. This paper compares some of the lipid components present in the large lake environments of Lake Michigan and Lake Huron with those of three marine sedimentary environments of the Northwest Atlantic. The lipid components investigated include fatty acids, hydrocarbons, and a hydroxy fraction containing straightchain alcohols, sterols, and hydroxy acids.

\section{Sampling}

\section{EXPERIMENTAL}

Surficial sediment samples were obtained from two Great Lakes and three marine locations (Fig. 1).

(1) Lake Michigan is the third largest of the North 


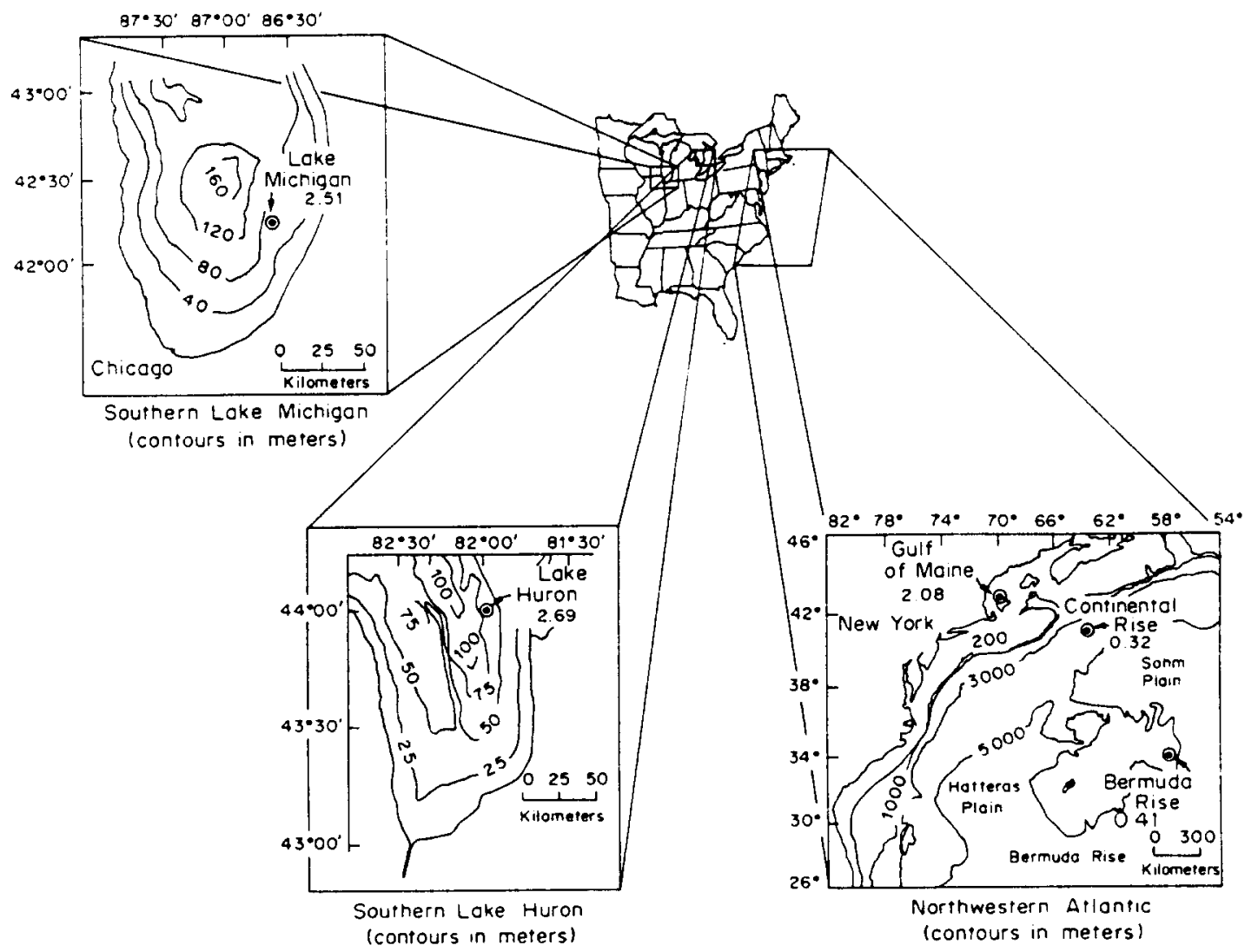

Fig. 1. Location and water depth profiles of surficial sediment samples. Total organic carbon $(\%)$ is given below sample locations.

American Great Lakes and is oligotrophic. The basin of Lake Michigan was shaped by the Wisconsin stage glaciation $12,000-25,000$ yr B.P. and contains sediments composed of glacial till overlain initially glacial-lacustrine clay and finally gray Holocene mud. The $2-2.5 \mathrm{~cm}$ section from a gravity core was obtained at Station 27 in $68 \mathrm{~m}$ of water in southern Lake Michigan. The sedimentation rate for this location was estimated to be $0.034-0.22 \mathrm{~cm} / \mathrm{yr}$ according to ${ }^{137} \mathrm{Cs}$ and ${ }^{14} \mathrm{C}$ dating (Leenheer, 1981). Total organic carbon (TOC) was $2.5 \%$.

(2) Lake Huron is the second largest of the North American Great Lakes and is similar to Lake Michigan in history and trophic status. The $2-3 \mathrm{~cm}$ section of a gravity core was obtained at Station $18 \mathrm{~A}$ in $65 \mathrm{~m}$ of water in the southeastern part of the lake. A sedimentation rate of $0.10 \mathrm{~cm} /$ year was estimated by ${ }^{210} \mathrm{~Pb}$ and ${ }^{14} \mathrm{C}$ geochronology (Bourbonniere, 1979). TOC was $\sim 2.7 \%$.

(3) The Gulf of Maine extends from Massachusetts to Nova Scotia and is bounded on its seaward side by Georges Bank and the Scotian Shelf. The bottom topography consists of a series of irregular closed basins which resulted from fluvial and glacial erosion and subsequent deposition during periods of lower sea level (Uchupi, 1965; Schlee, 1973). Box cores collected in September, 1977 on the $R / V$ Knorr Cruise
69, Leg 1 were obtained from J. W. Farrington of Woods Hole Oceanographic Institution. The $0-2 \mathrm{~cm}$ section of a core was obtained from the Wilkinson Basin in water depth of $250 \mathrm{~m}$. These coastal marine sediments were highly bioturbated by benthic fauna. Sedimentation rates were estimated to be $0.48-0.180 \mathrm{~cm} / \mathrm{yr}$ for this location (Repeta, unpublished manuscript); TOC values were approximately $2.0 \%$.

(4) A second box core from the $R / V$ Knorr Cruise 69 , was obtained from a depth of $4200 \mathrm{~m}$ on the continental rise east of the Gulf of Maine. The $0-4 \mathrm{~cm}$ interval was used for this study. TOC values were $0.3 \%$. The sedimentation rate is not known but is assumed to be low.

(5) Deep ocean sediments were obtained from the northern Bermuda Rise in the Atlantic Ocean. The Bermuda Rise is an elongated arch in the center of the North American Basin of the Atlantic Ocean. Laine (1977) suggests that the sediments on the northern Bermuda Rise consist of hemipelagic lutities accumulated as bottom current deposits originating from turbidities injected into the basin from the St Lawrence drainage system. Tucholke et al. (1977) support this interpretation and report that the surface unit of DSDP Site 382 located on the northern Bermuda Rise is distal turbidities with some material coming 
from the Canadian Maritime Province via the Laurentian Channel. The $0-4 \mathrm{~cm}$ section of a gravity core was obtained for this study from Bermuda Rise during the $R / V$ Oceanus Cruise 74 in December. 1979. The core was taken in water $4970 \mathrm{~m}$ deep. ${ }^{14} \mathrm{C}$ dating gave a sedimentation range of $0.012-0.74 \mathrm{~cm} / \mathrm{yr} ;$ TOC values were $\sim 0.4 \%$.

Samples were frozen and stored from the time of collection until analysis. Sediments from these five locations consist of silt-clay biogenic and clastic materials with no apparent stratigraphic inhomogeneity.

\section{Analytical methods}

The extraction scheme is outlined in Fig. 2. Sediment samples were initially acidified with $1 \mathrm{~N} \mathrm{HCl}$ to destroy carbonates which could bind some of the extractable lipids. After the carbonate was dissolved, the samples were extracted twice to yield first the unbound lipids and then the bound lipids (Fig. 2).

The unbound lipids were obtained by Soxhlet extraction with $2: 1$ toluene:methanol for $24 \mathrm{hr}$ followed by an additional $24 \mathrm{hr}$ extraction with $3: 1$ toluene:methanol. The lipid "unbound" extracts were then saponified using 2:1 $0.5 \mathrm{~N} \mathrm{KOH}$ in $95 \%$ methanol:toluene and methylated by heating with methanolic- $B F_{3}$. The sample residue from the Soxhlet extraction was saponified and methylated to yield the "bound" extract which represents lipids more tightly linked in the sediment matrix.

Each extract was separated into several fractions by column chromatography on a column made by packing $2 \mathrm{~g}$ of $5_{\%}^{\circ}$ deactivated aluminum oxide over $2 \mathrm{~g}$ of $5 \%$ deactivated silica gel. The column had a total height of $8 \mathrm{~cm}$ and a height/diameter ratio of $9 / 1$ and was successively eluted with petroleum ether $(10 \mathrm{ml}), 85: 15$ petroleum ether: benzene $(10 \mathrm{ml})$, benzene $(8 \mathrm{ml}), 1: 1$ ethyl acetate:benzene $(25 \mathrm{ml})$, and chloroform $(25 \mathrm{ml})$. This fractionation yielded eluants containing aliphatic and monoolefinic hydro-

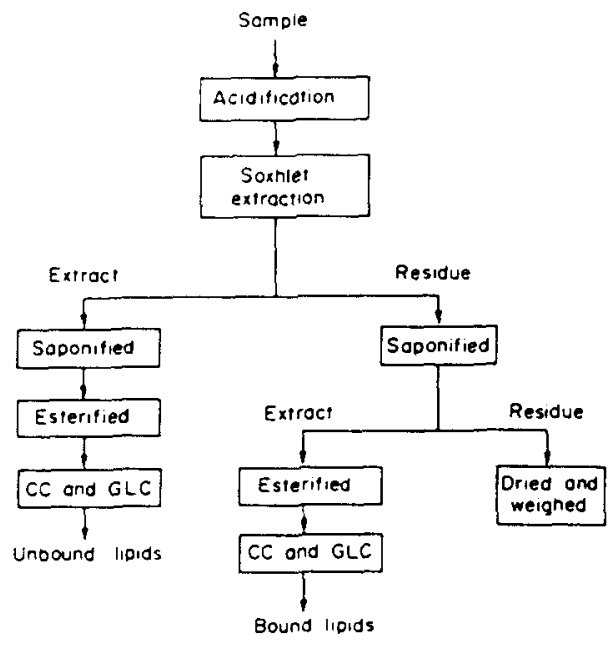

Fig. 2. Extraction scheme.

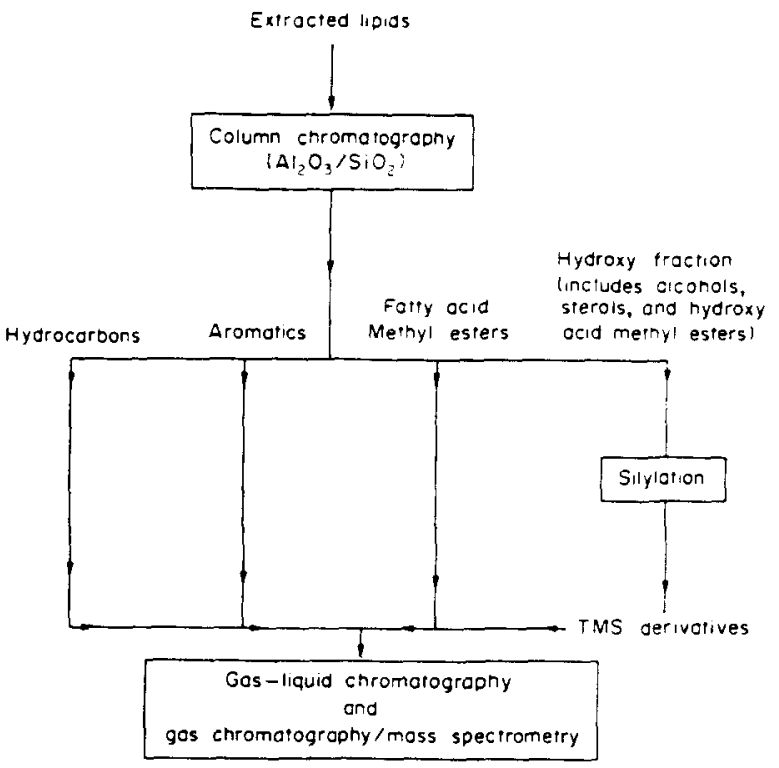

Fig. 3. Separation scheme.

carbons, aromatic hydrocarbons, fatty acid methyl esters, and hydroxy lipids, respectively (Fig. 3).

Quantitative and qualitative analysis of the components of the various fractions was done by gas-liquid chromatography on a HP 5830 gas chromatograph equipped with a HP model $18740 \mathrm{~B}$ capillary inlet system and single standard flame-ionization detector. The two glass capillary columns used were a $10 \mathrm{~m}$ SP2100 column (J\&W Scientific Inc.) and a $10 \mathrm{~m}$ SE-54 (H\&G Jaeggi) column. Hydrogen (prepurified) was used as a carrier gas with a flow at $1.5-2.0 \mathrm{ml} / \mathrm{min}$. Nitrogen was used as the makeup gas with a flow of $30 \mathrm{ml} / \mathrm{min}$. All samples were injected splitless with a splitless interval of one minute. Typically, the column was programmed from 70 to $150 \mathrm{C}$ at $30^{\circ} \mathrm{C} / \mathrm{min}$ and then from 150 to $270^{\circ} \mathrm{C}$ at $4^{\circ} \mathrm{C}$ min.

Quantitative standard mixtures were used to calculate response factors for known compounds. These response factors are relative to those of the internal standards used in the samples. Least squares regressions of response factors versus retention indices were done on the quantitative mix data to provide estimates of the response factors for those sample constituents which were not present in the standard mixture. $5 x$-cholestane, added just prior to injection. was used as the internal standard for hydroxy fraction. Hexatriacontane and heptadecanoic acid, added to each extract before saponification, were used as the internal standards for the hydrocarbon and fatty acid methyl ester fractions.

Selected hydroxy extracts were analyzed by GC-MS using a Finnigan Model 1015 Quadrupole Mass Spectrometer interfaced with a Varian model 1400 Gas Chromatograph which was equipped with a high temperature $20 \mathrm{~m} \times 0.32 \mathrm{~mm}$ i.d. glass capillary wall-coated open tubular (WCOT) column coated with SE-52. Helium was used as a carrier gas 
with a column head pressure of $6 \mathrm{psi}$. The samples were injected in splitless mode at room temperature and at $t=3 \mathrm{~min}$, the column was programmed from 70 to $160^{\circ} \mathrm{C}$ at $8^{\circ} \mathrm{C} / \mathrm{min}$, followed by a rate of $4^{\circ} \mathrm{C} / \mathrm{min}$ from 160 to $310^{\circ} \mathrm{C}$. The injection temperature was $300^{\circ} \mathrm{C}$. Electron impact spectra were obtained on the resolved compounds at an ionization voltage of $40 \mathrm{eV}$.

\section{RESULTS AND DISCLSSION}

\section{The influence of lipid sources}

The distributions of lipid components found in sediments have been commonly related to the sources of the lipids (Simoneit, 1987). $C_{23}-C_{33} n$-alkanes, $\mathrm{C}_{22}-\mathrm{C}_{30} n$-alkanoic acids, and $\mathrm{C}_{22}-\mathrm{C}_{30} n$-alkanols with high odd and even carbon preferences imply terrigenous sources. Evidence of aquatic sources is not so easily found because many compounds present in aquatic organisms also occur in land plants, yet $\mathrm{C}_{12}-\mathrm{C}_{20} n$-alkanes appear to be positive indicators of aquatic origin. Among these hydrocarbons, $n$ heptadecane is particularly useful as an indicator of plankton, although sometimes subject to diagenesis (cf. Giger et al., 1980). Furthermore, the relative dominance of $\mathrm{C}_{27}$ sterols in aquatic organisms and $\mathrm{C}_{29}$ sterols in land plants can be used to distinguish between these sources of organic matter in young sediments (Huang and Meinschein, 1976, 1979; Nishimura and Koyama, 1977; Leenheer, 1981).

To compare the differences in relative amounts of aquatic versus terrigenous lipid inputs to the surficial sediments, sample locations were chosen increasing in distance from shore and increasing in water depth The Great Lakes (LM and LH) sediment samples were closest to shore and from the most shallow water, followed by the Gulf of Maine (GM), the Continental Rise (CR), and the Bermuda Rise (BR) samples, respectively.

Table 1 summarizes the lipid data for the unbound and bound extracts of these five surficial sediment samples. With increasing transport distance, the general increases in $n-\mathrm{C}_{17} / n-\mathrm{C}_{29}$ alkane, $n-\mathrm{C}_{16} / n-\mathrm{C}_{26}$ alcohol, and 16:0/24:0 fatty acid ratios (Fig. 4) reflect that, farther from shore, the aquatic (short chain) component becomes more important than the longer chain component. With the exception of the alkane ratios of the Great Lakes samples, the bound aquatic/terrigenous ratios are larger than the unbound ratios, suggesting that the bound extract has a more aquatic character than the unbound extract. This bound extract may reflect input from aquatic biota which is released upon saponification. The large $n-C_{17} / n-C_{29}$ alkane ratios of the Great Lakes unbound extracts may refect a large planktonic input at that station.

Although $\mathrm{C}_{27} / \mathrm{C}_{24}$ sterol ratios can be used as indicators of aquatic vs terrigenous inputs, some marine organisms produce $C_{29}$ sterols which are difficult to separate from the higher plant $\mathrm{C}_{2 y}$ sterols by standard chromatographic methods (Wardroper et al., 1978; Lee et al., 1980). Thus, the similar $C_{27} / C_{24}$ sterol ratios observed for the four locations (Fig. 4) may reflect mixtures of land-derived and marinederived $\mathrm{C}_{29}$ sterols. However, the smaller $\mathrm{C}_{2 .} \mathrm{C}_{24}$ ratio found in the Continental Rise sample also agrees with
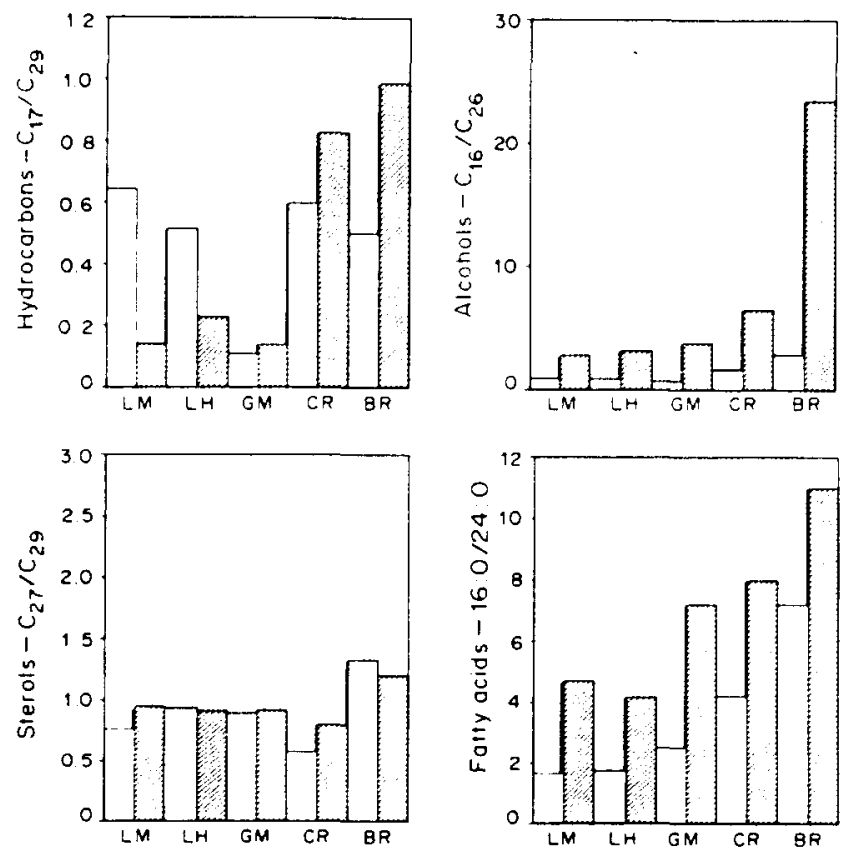

Fig. 4. Possible aquatic/terrigenous indicators represented by ratios of short chain to long chain components of hydrocarbons, alcohols, sterols, and fatty acids. $L M=$ Lake Michigan; $L H=$ Lake Huron: $\mathrm{G} \cdot \mathrm{M}=$ Gulf of Maine: $\mathrm{CR}=$ Continental Rise: $\mathrm{BR}=$ Bermuda Rise. Solid Bars represent unbound extracts and hatched bars represent bound extracts. 


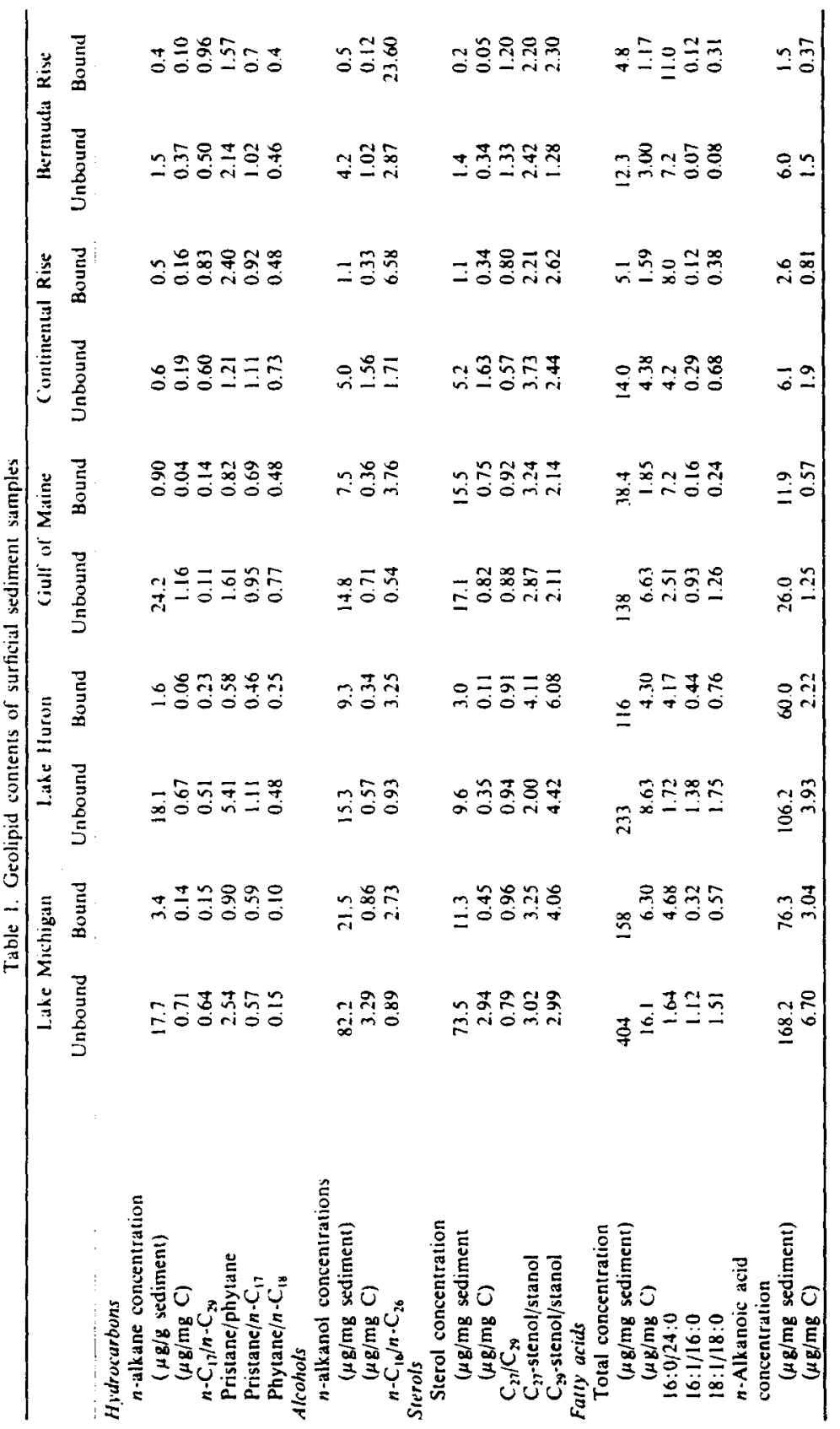


the study of Lee et al. (1979) in which an increase in $C_{39}$ sterols relative to $C_{23}$ sterols was found with increased distance from shore in the North Atlantic. The $\mathrm{C}_{39}$ sterols present in the Continental Rise sample may be terrigenous components transported southward with sediments from the Labrador Sea by the Western Boundary Undercurrent (Zimmerman, 1972). However, the terrigenous composition should

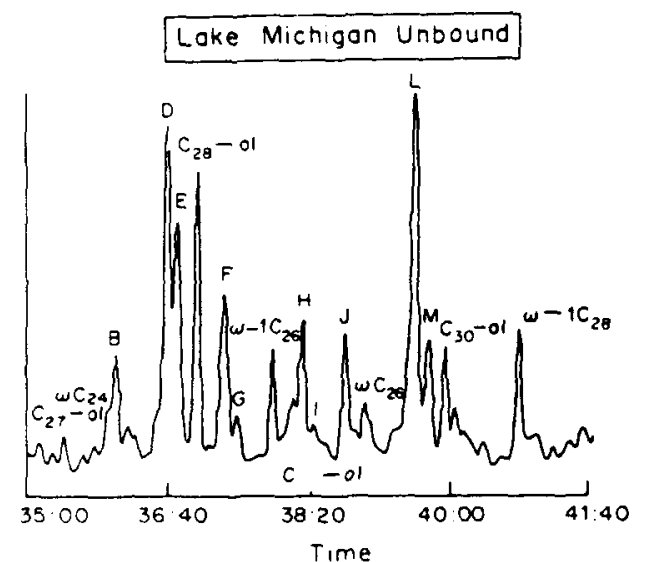

then be reflected in the straight chain data, which it is not, and so, the sterol ratios more likely reflect $\mathrm{C}_{39}$ components in marine samples.

The samples can be divided into near shore and open ocean categories on the basis of lipid character. The Great Lakes sediments and Gulf of Main sediment have similar straight chain distributions, indjcating similar types of sources for the lipid matter at

\begin{tabular}{|c|c|c|}
\hline & \multicolumn{2}{|l|}{ Peak identifications for the hydroxy extracts } \\
\hline Symool & \multicolumn{2}{|l|}{ Idensification } \\
\hline ol & \multicolumn{2}{|l|}{ Straight choin alconols } \\
\hline$\omega, \omega-1$ & \multicolumn{2}{|l|}{ Mydroxy fatiy ocids } \\
\hline A & $27-$ nor $-24-$ methylcholesta- $-5.22-$ dien $-3 \beta-01$ & \\
\hline 8 & Cholesto-5.22-dien $-3 \beta-01$ & \\
\hline C & $5 \alpha-$ Cnolest $-22-0 n-3 \beta-01$ & $\begin{array}{l}C_{27} \\
\text { sterols }\end{array}$ \\
\hline $\mathrm{D}$ & Cholest $-5-e n-3 \beta-$ ol (cholesterol) & \\
\hline$E$ & $5 a-$ Cnoleston $-3 \beta-$ ol (cholestonol) & \\
\hline$\vec{F}$ & $24-$ Met hylcholesta-5.22-dien $-3 \beta$-al (brassicasterol/erinosterol) & \\
\hline G & $24-$ Mathyl $-5 \alpha-$ cholest $-22-8 n-3 \beta-01$ & \\
\hline H & $24-$ Methylenolest $-5-e n-3 \beta-01$ (compesterol) & sterols \\
\hline 1 & 24 - Meinyl-5a-choleston $-3 \beta-01$ & \\
\hline J & $24-E$ inylenolesia -5.22 -dien $-3 \beta-$ ol (stigmosterol/poriferosierol) & \\
\hline$k$ & $24-E$ inyl $-5 a-c$ holest $-22-e n-3 \beta-o l$ & \multirow{3}{*}{$\begin{array}{c}\mathrm{C}_{20} \\
\text { sterols }\end{array}$} \\
\hline$L$ & $24-E$ thylcholest $-5-$ en $-3 \beta-01$ ( $\beta-$ sitosterol / clionosterol) & \\
\hline M & $24-$ Ethyl-5a-chalesion $-3 \beta-01$ & \\
\hline
\end{tabular}
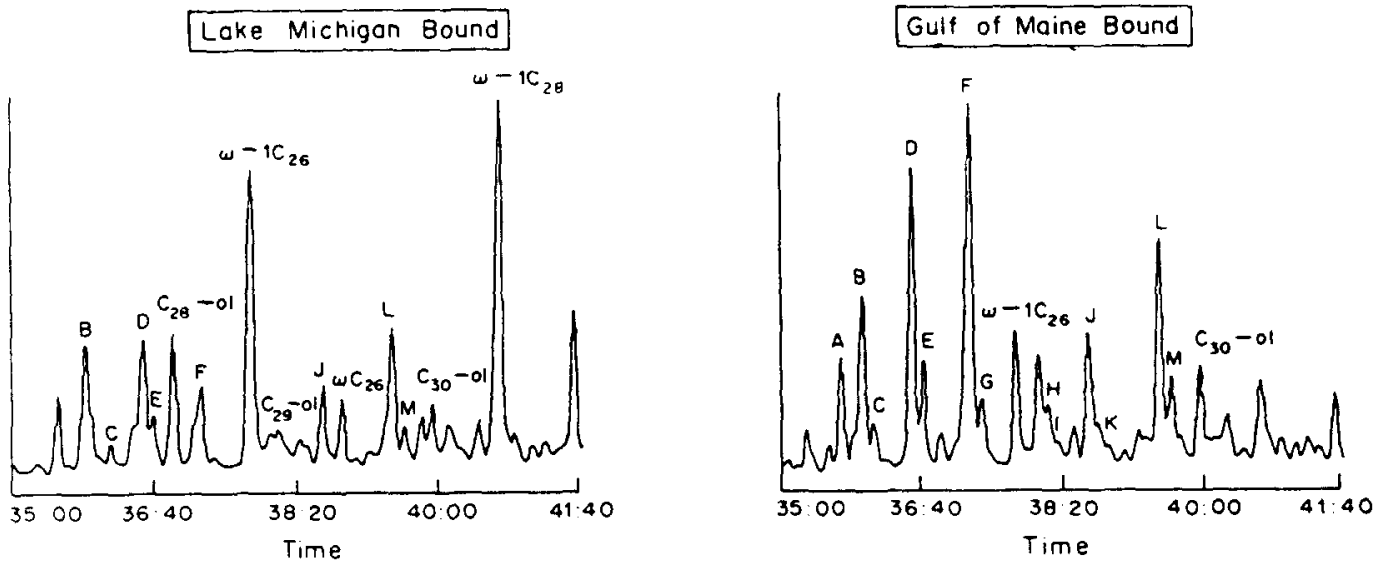

Fig. 5. Ion chromatograms of hydroxy fraction of Lake Michigan and Gulf of Maine surficial sediment samples. 
these locations. These locations can be contrasted with the open ocean stations, the Continental Rise, and Bermuda Rise sediments, which contain significantly less "terrigenous" lipids.

Finally, one additional difference was evident between the lacustrine and marine sediment lipids. The lacustrine sediments (LM and LH) are dominated by a small number of sterols, while the marine sediment contains more complex sterol patterns (Fig. 5), especially in the bound fraction. Similar differences in distributions have been found in other studies (Lee et al., 1977, 1980; Nishimura, 1977) reflecting the greater diversity of sterols present in the ocean biota.

\section{The influence of diagenesis}

One measure of the amount of diagenesis which the lipids experience before and during deposition is the degree of unsaturation present in the surficial sediment samples. The fatty acid 16:1/16:0 and $18: 1 / 18: 0$ ratios as well as the stenol/stanol ratios are compared in Fig. 6 and Table 1. While some degradation of unsaturated fatty acids may occur during transport, studies of fatty acids present in sediment traps (Meyers et al., 1980) indicate that bacteria actively produce $16: 1$ throughout the water column. With increasing distance from shore, the fatty acid $16: 1 / 16: 0$ and $18: 1 / 18: 0$ ratios decrease, suggesting that increased degradation of the unsaturated components is occurring in the surficial sediments. The lower sedimentation rate at the open ocean station allows more degradation to occur than at the nearshore stations and probably is a major factor for the observed decreases in fatty acid ratios. Also, it appears that the unsaturated fatty acids present in the unbound fraction are more subject to diagenesis than those in the bound extract since there are rapid decreases in the unbound ratios while the bound ratios decrease only slightly.

Unlike the fatty acid ratios, the stenol/stanol ratios do not show the marked decreasing trend with increasing distance from shore (Fig. 6). This could be the result of slower degradation of sterols relative to fatty acids (Cranwell, 1981; Leenheer, 1981). However, the smallest stenol/stanol ratios are present at the Bermuda Rise station which also has the lowest sedimentation rate. The larger $\mathrm{C}_{29}$ stenol/stanol ratios present in the lacustrine sample may reflect a larger input of plant stenols to these locations relative to the marine samples.

Pristane/phytane and stenol/stanol ratios have been used as a measure of the sediment oxicity (Didyk et al., 1978; Gagosian et al., 1980). The pristane/phytane ratios in the unbound extracts of the samples are all greater than unity, suggesting that all the samples were taken from primarily oxic envi-
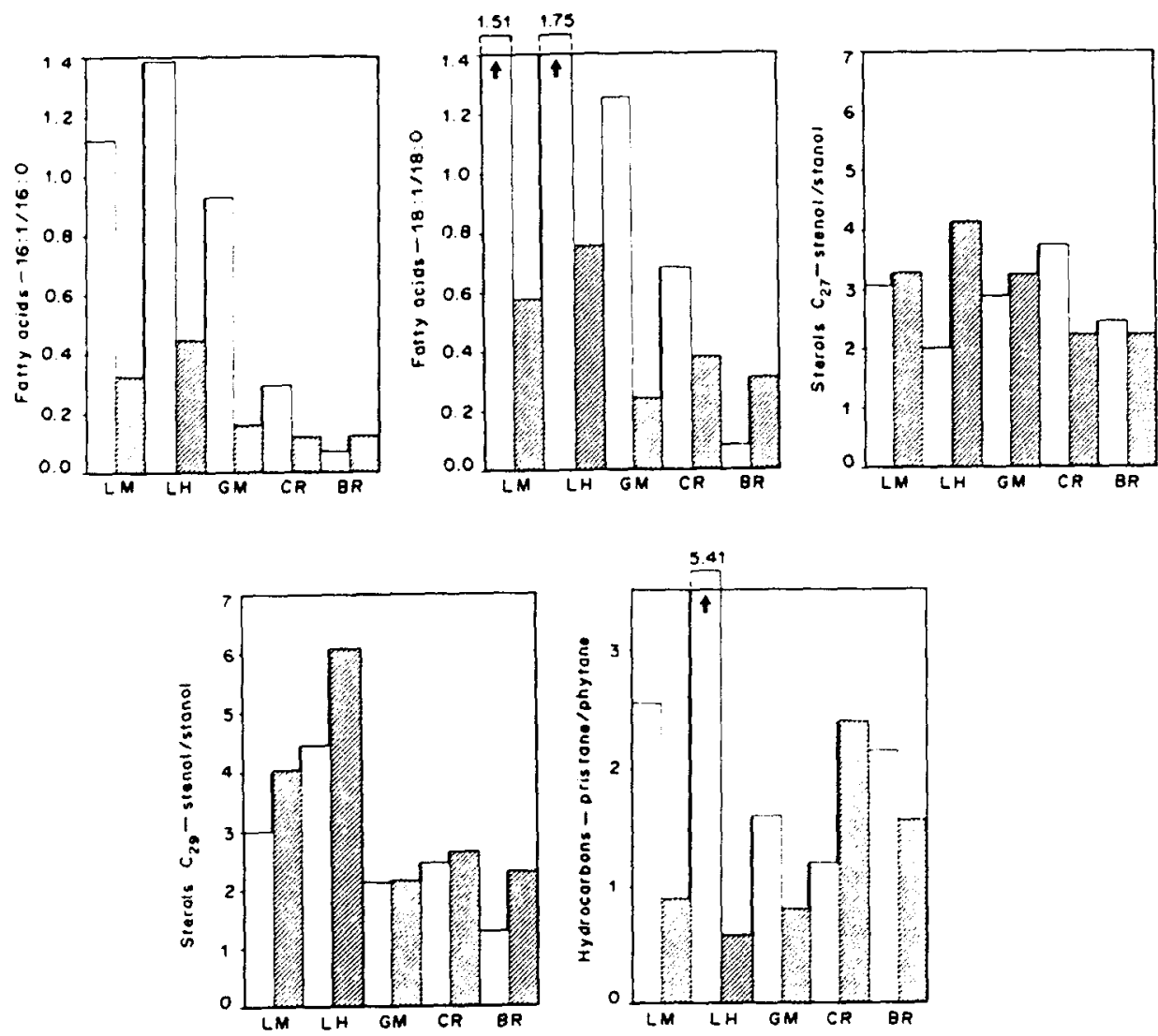

Fig. 6. Potential alteration indicators represented by ratios of $\mathrm{C}_{16}$ and $\mathrm{C}_{18}$ fatty acids, $\mathrm{C}_{27}$ and $\mathrm{C}_{29}$ sterols and isoprenoid hydrocarbons. Key is the same as that of Fig. 4. 
ronments. The differences between the bound and unbound ratios again reflect the different material existing in these two extracts. The relatively high stenol/stanol ratios also indicate an oxic depositional environment. No definite trend is observed in the pristane/phytane ratios from the four samples. suggesting that diagenesis and sedimentation rate differences have little or no affect on these ratios.

\section{Combined influence of sources and diagenesis}

Lipid concentrations can be affected significantly by both source changes and diagenetic alteration. The TOC values and sedimentation rates differ significantly in the five sediment environments. The sedimentation rate differences are responsible. in part, for the amount of lipid material preserved in the sediment. The low sedimentation rates of the Bermuda Rise sample provide for little preservation of lipid material since degradational processes can act more completely upon the lipids before burial in the sediment. The Great Lakes and Gulf of Maine sediments have higher sedimentation rates resulting in greater preservation of lipid material than occurs in the Bermuda Rise sediments. However, the amount of organic matter preserved is also related to the amount of organic matter input to the sediment. In this regard, the locations closer to shore and in shallower water have larger inputs of organic matter to the sediments than those stations more distant from shore.

Figure 7 and Table 1 present the total lipid concentrations present in the five surficial sediment samples. With increasing distance from shore, total lipids, including alkane, alkanol, sterol, and alkanoic acid concentrations in units of $\mu \mathrm{g} / \mathrm{g}$ sediment, generally decrease in the bound and unbound sediment extracts. This could reflect a decrease in amount of input organic matter, dilution of organic matter with increasing distance from shore, and/or increased diagenesis of organic material due to lower sedimentation rates. Lee et al. (1979) found similar trends in a study of Northwestern Atlantic sediments

Since the TOC varies significantly at these five locations, the unbound alcohol and sterol concentrations in $\mu \mathrm{g} / \mathrm{mg}$ carbon (Table 1) are smaller in the Gulf of Maine and Lake Huron sediments than in the remaining sediment samples. The alkane and fatty acid concentrations as well as the bound alcohol concentrations in $\mu \mathrm{g} / \mathrm{mg}$ carbon generally decrease distance from shore but to a smaller extent than the $\mu \mathrm{g} / \mathrm{g}$ sediment concentrations, suggesting that the character of the organic matter also changes with increasing distance from shore. Since the lipid character and concentrations of these five stations are both changing, these variations probably reflect both source-related and diagenetic changes.
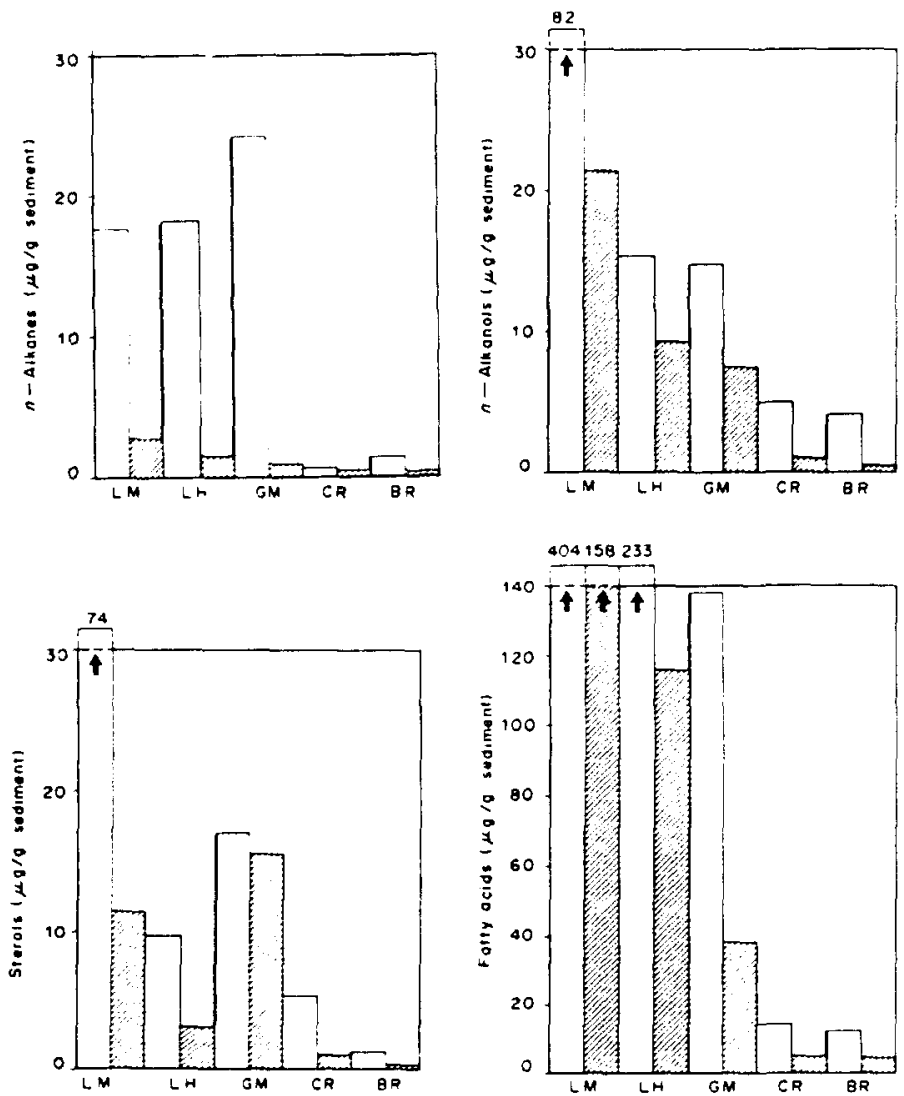

Fig. 7. Total concentrations of hydrocarbons. alcohols. sterols, and fatty acids. Key is the same as that of Fig. 4. 
Table 2. Percentage bound extract present in surficial sediment samples

\begin{tabular}{lccccc}
\hline & $\begin{array}{c}\text { Lake } \\
\text { Michigan }\end{array}$ & $\begin{array}{c}\text { Lake } \\
\text { Huron }\end{array}$ & $\begin{array}{c}\text { Gulf } \\
\text { of Maine }\end{array}$ & $\begin{array}{c}\text { Continental } \\
\text { Rise }\end{array}$ & $\begin{array}{c}\text { Bermuda } \\
\text { Rise }\end{array}$ \\
\hline$n$-Alkanes & 16 & 8 & 4 & 47 & 21 \\
$n$-Alcohols & 21 & 38 & 34 & 17 & 10 \\
Sterols & 13 & 24 & 48 & 17 & 12 \\
$n$-Alkanoic acids & 31 & 36 & 22 & 27 & 28 \\
\hline
\end{tabular}

The unbound and bound extracts differ in lipid concentrations and distributions. The concentrations of the unbound extracts are 2-10 times larger than the bound concentrations. The bound extracts have more short chain components relative to long chain components than the unbound extracts. This suggests that the bound extracts have larger inputs in aquatic material.

Comparison of the extracts of the five sediment samples reveals that the percentage bound remains relatively constant for fatty acids (Table 2 ). With the exception of the Lake Michigan sample the percentage of the total extract, which is present in the bound form. decreases for the alcohols and sterols with increasing distance from shore (Table 2). Alternatively, the large amounts of bound sterols and alcohols present in the Gulf of Maine and Lake Huron sediments could result from the input of more terrigenous humic matter at those locations. However. since the bound extracts have a more aquatic character than the unbound extracts, these relatively large amounts of bound sterols and alcohols could also represent contributions from aquatic biota. The largest percentage bound for the alkane fraction is found in the Continental Rise sediment. Lee et al. (1979) found more bound sterols at the open ocean stations than at the bay stations in the North Atlantic, which agrees with the hydrocarbon data but not the sterol and alcohol data of this study. Lee et al. (1977) also suggested that a conversion from unbound material occurs downcore while Nishimura (1977) found no such conversion occurring. Leenheer (1981) postulates conversion occurring in Gulf of Maine sediments but not in Lake Michigan sediments. Thus, the amount of lipids existing in a bound form seems to be related both to specific organic inputs to the sediment and to alterations occurring there. These conditions can vary significantly in different depositional environments and represent an area where further research is needed.

\section{CONCLUSIONS}

(1) With increasing distance from shore, the amount of terrigenous-sourced lipid material decreases.

(2) A significant different between the lacustrine sample and the marine samples is a larger variety of sterols present in the marine environment, which probably reflects the greater diversity of marine biota.

(3) With increasing distance from shore, the relative amount of unsaturated fatty acids decreases relative to saturated fatty acids in the unbound extracts while the proportions remain relatively constant in the bound extracts. This suggests that the unbound unsaturated components are more available for diagenesis than their bound counterparts.

(4) Ratios of pristane/phytane are greater than unity and those of stenol/stanol are relatively large, suggesting that all samples were deposited in predominantly oxic depositional environments.

(5) In general, lipid concentrations decrease with distance from shore probably resulting from a combination of smaller inputs of organic material and slower sedimentation rates allowing for more diagenesis of the lipids.

(6) The bound extract in all the samples has a more aquatic character than the unbound extracts as evidenced by larger proportions of short chain relative to long chain components at all stations.

Acknowledgements - We thank O. E. Kawka for his helpful comments to improve this paper. We are particularly grateful to J. W. Farrington for making possible access to the marine sediment samples and to N. M. Frew for his assistance in GC-MS analyses. Parts of this research were supported by the Earth Science Division of the National Science Foundation (Grant EAR7822432).

\section{REFERENCES}

Brooks P. W., Eglinton G., Gaskell S. J., McHugh D. J., Maxwell J. R. and Philp R. P. (1976) Lipids of recent sediments, part I: Straight-chain hydrocarbons and carboxylic acids of some temperate lacustrine and subtropical lagoonal/tidal flat sediments. Chem. Geol. 18, 21-38.

Brooks P. W., Eglinton G.. Gaskell S. J., McHugh D. J., Maxwell J. R. and Philp R. P. (1977) Lipids of recent sediments, part II. Branched and cyclic alkanes and alkanoic acids of some temperate lacustrine and subtropical lagoonalitidal flat sediments. Chem. Geol. 20, 189-204.

Bourbonniere R. A. (1979) Geochemistry of humic matter in Holocene Great Lakes sediments: Ph.D. dissertation. University of Michigan, Ann Arbor.

Cranwell P. A. (1977) Organic geochemistry of Cam Loch (Sutherland) sediments. Chem. Geol. 20, 205-221.

Cranwell P. A. (1978) Extractable and bound lipid components in a freshwater sediment. Geochim. Cosmochim. Acta 42, 1523-1532.

Cranwell P. A. (1981) Diagenesis of free and bound lipids in terrestrial detritus deposited in a lacustrine sediment. Org. Geochem. 3, 79-89.

Didyk B. M. Simoneit B. R. T., Brassell S. C. and Eglinton G. (1978) Organic geochemical indicators of paleoenvironmental conditions of sedimentation. Vature 272. 216-222.

Gagosian R. B.. Smith S. O.. Lee C., Farrington J. W. and Frew N. M. (1980) Steroid transformations in recent marine sediments. In Adrances in Organic Geochemistry 
1979 (Edited by Douglas A. G. and Maxwell J. R.), pp. 407-419. Pergamon Press.

Gaskell S. J. and Eglinton G. (1976) Sterols of a contemporary lacustrine sediment. Geochim. Cosmochim. Acta 40, 1221-1228.

Gearing P., Gearing J. N., Lytle T. F. and Lytle J. S. (1976) Hydrocarbons in 60 northeast Gulf of Mexico shelf sediments: A preliminary survey. Geochim. Acta $\mathbf{4 0}$. 1005-1017.

Giger W., Schaffner C. and Wakeham S. G. (1980) Aliphatic and olefinic hydrocarbons in Recent sediments of Greifensee, Switzerland. Geochim. Cosmochim. Acta 44, 119-129.

Huang W. Y. and Meinschein W. G. (1976) Sterols as source indicators of organic materials in sediments. Geochim. Cosmochim. Acla 40, 323-330.

Huang W. Y. and Meinschein W. G. (1978) Sterols in sediments from Baffin Bay, Texas. Geochim. Cosmochim. Acta 42, 1391-1396.

Huang W. Y. and Meinschein W. G. (1979) Sterols as ecological indicators. Geochim. Cosmochim. Acta 43, 739-745.

Laine E. P. (1977) Geological effects of the Gulf Stream system in the North American basin. Ph.D. Dissertation, Massachusetts Institute of Technology/Woods Hole Oceanographic Institution Joint Program in Oceanography.

Lee C., Farrington J. W, and Gagosian R. B. (1979) Sterol geochemistry of sediments from the Western North Atlantic Ocean and adjacent coastal areas. Geochim. Cosmochim. Acta 43, 35-46.

Lee C., Gagosian R. B. and Farrington J. W. (1977) Sterol diagenesis in recent sediments from Buzzards Bay, Massachusetts. Geochim. Cosmochim. Acta 41, 985-992.

Lee C., Gagosian R. B. and Farrington J. W. (1980) Geochemistry of sterols in sediments from Black Sea and the southwest African shelf and slope: Org. Geochem. 2, $102-113$.

Leenheer M. J. (1981) Use of lipids as indicators of diagenetic and source related changes in Holocene sediments. Ph.D. Dissertation, University of Michigan.
Meyers P. A., Edwards S. J. and Eadie B. J. (1980) Fatty acid and hydrocarbon content of settling sediments in Lake Michigan. J. Great Lakes Res. 6, 331-337.

Meyers P. A. and Takeuchi N. (1979) Fatty acids and hydrocarbons in surficial sediments of Lake Huron. Org. Geochem. 1, 127-138.

Nishimura M. and Koyama T. (1976) Stenols and Stanols in lake sediments and diatoms. Chem. Geol. 17, 229-239.

Nishimura M. and Koyama T. (1977) The occurrence of stanols in various living organisms and the behavior of sterols in contemporary sediments. Geochim. Cosmochim. Acta 41, 379-385.

Nishimura M. (1977) The geochemical significance in early sedimentation of geolipids obtained by saponification of lacustrine sediments: Geochim. Cosmochim. Acta 41 , $1817-1823$.

Reed W. E. (1977) Biogeochemistry of Mono Lake, California. Geochim. Cosmochim. Acta 41, 1231-1245.

Repeta $\mathrm{D}$. J. (unpublished manuscript) ${ }^{210} \mathrm{~Pb}$ geochronology of Gulf of Maine sediments.

Schlee J. (1973) Atlantic continental shelf and slope of the United States: Sediment texture of the northeastern part. U.S. Geol. Surv. Prof. Pap. 529-L, 64 pp.

Simoneit B. R. T. (1978) The organic chemistry of marine sediments. In Chemical Oceanoraphy (Edited by Riley J. P. and Chester R.), pp. 233-311. Academic Press.

Tucholke B. E., Vogt P., McCave I. N., Murdmaa I. O. Rothe P., Houghton R. L., Galehouse J., Kaneps A., McNulty C., Okada H.. Kendrick J. and Demurs K. (1977) Initial Reports of the Deep Sea Drilling Project 43. U.S. Govt Printing Office, Washington, DC.

Uchupi E. (1965) Basins of the Gulf of Maine. U.S. Geol. Surv. Prof. Pup. 525-D, pp. D175-D177.

Wardroper A. M. K., Maxwell J. R. and Morris R. J. (1978) Sterols and diatomaceous ooze from Walvis Bay. Steroids 32, 203-221.

Zimmerman H. B. (1972) Sediments of the New England Continental Rise. Geol. Soc. Am. Bull. 83, 3700-3724. 